Jurnal Ilmiah Farmasi (Scientific Journal of Pharmacy) 17(2) Agustus-Desember 2021, 210-225

ISSN: $1693-8666$

available at http://journal.uii.ac.id/index.php/JIF

\title{
The identification of drug related problems (DRPs) using profilaxis antibiotics in orthopedic surgical patients at a Government Hospital in Yogyakarta
}

\section{Identifikasi drug related problems (DRPs) penggunaan antibiotik profilaksis pada pasien bedah ortopedi di Rumah Sakit Pemerintah Yogyakarta}

\author{
Happy Elda Murdiana
}

Universitas Kristen Imanuel, Yogyakarta

*Corresponding author: happy@ukrimuniversity.ac.id

\begin{abstract}
Background: Antibiotic prophylaxis in orthopedic surgery cases aims to prevent surgery site infections (SSI). For antibiotic prophylaxis, it is recommended to use the first generation of cephalosporin, namely cefazolin which can kill the bacteria commonly found in orthopedic surgery infection. The prophylactic administration of cefotaxime is not the first line but is definitive for surgical prophylaxis.

Objective: The aim of this study was to determine the rationale for the use of antibiotic prophylaxis for orthopedic surgery, the drug problems (DRPs) that occurred and their potential interactions.

Method: This study was conducted using a cross sectional design with a total sampling technique of medical record samples from January to February 2019 at the Government Hospital in Yogyakarta. Observational analytical descriptive data processing by ensuring the appropriate of indications, route of administration, timing of administration and an appropriate of prophylactic doses as well as how to compare DPRs to the literature and analysis of potential co drug interaction with Drug Information Handbook (DIH), AHFS Clinical Drug Information, Drug Interaction Facts and Interactions Stockley's Drug Interaction.

Results: All patients received appropriate therapy for indication, type of drug, routes of administration for pre and postoperative. All patients received an under dose of ranitidine and 1 patient $(1,69 \%)$ received an over dose of piracetam. Potential interactions that occur include ketorolac-ranitidine, NSAIDs with other NSAIDs, NSAIDs-ranitidine, NSAIDs-ACEi, NSAIDs-bisoprolol, bisoprolol-calcium, calcium-vitamin C, and paracetamol-ranitidine.

Conclusion: Pre and postoperative prophylactic antibiotics are rational. The accompanying drug, ranitidine and piracetam were not properly doses. Drug interactions in this study are potential.

Keywords: prophylaxis antibiotic, orthopedic surgery, cefotaxim, DRPs

\section{Intisari}

Latar belakang: Profilaksis antibiotic pada kasus bedah ortopedi bertujuan mencegah timbulnya Infeksi Luka Operasi (ILO). Profilaksis antibiotik untuk bedah disarankan menggunakan sefalosporin generasi pertama yaitu cefazolin yang dapat membunuh bakteri $s$. aureus yang biasa terdapat pada infeksi bedah ortopedi. Pemberian profilaksis cefotaxim bukan lini pertama tetapi direkomendasikan untuk profilaksis bedah.

Tujuan: Penelitian ini bertujuan mengetahui kerasionalan (DRPs) penggunaan antibiotik profilaksis bedah ortopedi dan obat penyerta yang diberikan.

Metode: Penelitian ini menggunakan metode rancangan cross sectional, teknik total sampel dilakukan dalam pengambilan sampel rekam medis bulan Januari-Februari 2019 di Rumah Sakit Pemerintah di Yogyakarta. Pengolahan data deskriptif analitik observasional dengan menganalisa ketepatan indikasi, jenis obat, rute pemberian, waktu pemberian dan ketepatan dosis antibiotic profilaksis serta obat penyerta dengan cara membandingkan DRPs terhadap literatur dan menganalisa potensi interaksi obat penyerta dengan buku Drug
\end{abstract}


Information Handbook (DIH), AHFS Clinical Drug Informaton, Interaction Drug Fact, dan Stockley's Drug Interaction.

Hasil: Semua pasien mendapatkan terapi tepat indikasi, jenis obat, rute pemberian, dan tepat dosis pemberian obat untuk pre dan paska pembedahan. Semua pasien menerima dosis kurang untuk terapi penyerta ranitidin dan 1 pasien $(1,69 \%)$ menerima piracetam dosis berlebih. Potensial interaksi yang terjadi meliputi ketorolak-ranitidin, NSAID dengan NSAID lain, NSAID-ranitidin, NSADI-ACEI, NSAID-bisoprolol, bisoprolol-kalsium, kalsium-vitamin C, dan paracetamol-ranitidin

Kesimpulan: Pemberian antibiotic profilaksis pra dan paska pembedahan rasional. Obat penyerta berupa ranitidin dan piracetam tidak tepat dosis. Interaksi obat pada penelitian ini bersifat potensial.

Kata kunci: antibiotik profilaksis, bedah ortopedi, cefotaxim, DRPs

\section{Pendahuluan}

Cidera lalu lintas menjadi penyebab kematian utama dan cidera yang tidak disengaja menduduki penyebab kematian kedua. Asia Tenggara menyumbang 60\% dari kematian akibat cidera (WHO, 2021 ). Riskesdas 2013 melaporkan jenis cidera patah tulang di Indonesia mencapai 5,8\%. Angka kejadian patah tulang di Indonesia menjadi penyebab kematian terbanyak ketiga dibawah penyakit jantung koroner dan tuberculosis (Kemenkes-RI, 2013). Kejadiaan fraktur yang menyebabkan dilakukannya tindakan bedah ortopedi mencapai 50\% dari kasus bedah orthopedi (Yekti, 2008). Infeksi pada bedah ortopedi merupakan hal yang sering terjadi dan ditakuti, karena berhubungan dengan morbiditas yang panjang, kecacatan dan peningkatan mortalitas (Dhammi et al., 2015). ILO merupakan salah satu infeksi nosokomial yang paling sering terjadi selain infeksi saluran kemih, pneumonia dan bakterimia. Insiden ILO pasien kasus bedah ortopedi lebih banyak dibandingkan kasus bedah lain yaitu 71\% dari kasus bedah keseluruhan. Lama waktu menginap pasien bedah ortopaedi dengan ILO mengalami peningkatan 2x lipat dibanding pasien rawat inap pada umumnya. Pasien bedah ortopedi mengalami keterbatasan fisik sehingga menyebabkan peningkatan biaya kesehatan sampai 30\% akibat infeksi (Saffanah, 2020). Angka kejadian ILO dalam kasus bedah ortopedi di rawat inap maupun rawat jalan RS Fatmawati pada bulan JuliOktober 2018 adalah 3,9\% dengan faktor resiko yang signifikan berupa diabetes mellitus (Asrawal et al., 2019). Faktor resiko ILO lainnya berupa obesitas, malnutrisi dan faktor operasi berupa lama operasi dan prosedur operasi juga mempengaruhi ILO (Marsaoly, 2016). Penelitian terdahulu membuktikan antibiotik sebagai profilaksis infeksi mempunyai efektifitas sebesar lebih dari 50\% pada kasus fraktur terbuka dan menurunkan insiden superfisial serta infeksi dalam sebanyak 4,7\% dibanding plasebo (Bryson et al., 2016). Penggunaan antibiotik profilaksis dapat mencegah timbulnya ILO dalam kasus bedah ortopedi yang melibatkan penanaman prostesis atau penggunaan bahan osteosintetik, seperti pelat, paku, kawat, dan sekrup. Menurut beberapa 
pedoman nasional dan internasional, penggunaan profilaksis antibiotik dalam kasus bedah ortopedi berupa cefazolin yaitu sefalosporin generasi pertama merupakan antibiotik pilihan pertama sebagai profilaksis untuk mencegah ILO (Radji et al., 2014). Cefazolin merupakan agen yang direkomendasikan selain cefuroxime di sebagian besar pedoman bedah ortopedi. Banyak ahli setuju perbedaan dan dampak ekologi antara kedua sefalosporin generasi kedua ini minimal, karena keduanya mirip dalam hal spektrum klinis dan kemanjuran (Davat et al., 2018). Penggunaan dan pemilihan antibiotik sebagai profilaksis harus tepat jenis dan golongannya, serta mempertimbangkan kadar antibiotik di dalam jaringan dari mulai saat berlangsung hingga operasi selesai dilakukan (Dinata, 2018) sehingga akan menghindari DRPs penggunaan antibiotik profilaksis.

Drug related problems (DRPs) merupakan kejadian yang melibatkan terapi obat yang menimbulkan efek aktual maupun potensial yang dapat mempengaruhi terapi optimal pasien (Jamal et al., 2015; Mil et al., 2019). Pharmaceutical Care Network Europe association (PCNE) mengklasifikasikan DRPs berdasarkan kategori permasalahan, penyebab dan intervensi yang diberikan (Mil et al., 2019). Penelitian sebelumnya mengidentifikasi kasus DRPs penggunaan antibiotik profilaksis di unit bedah ortopedi kasus fraktur di RS Panti Rapih Yogyakarta diperoleh adanya 4 kasus yaitu terapi tanpa indikasi, dosis terlalu rendah, dosis terlalu tinggi, dan efek obat merugikan (Yekti, 2008). Tujuan penelitian ini mengidentifikasi adanya DRPs penggunaan antibiotik profilaksis dan obat penyerta lainnya pada pasien kasus bedah ortopedi di Rumah Sakit Pemerintah Yogyakarta sehingga dapat mencegah efek merugikan pada pasien.

\section{Metodologi penelitian}

\subsection{Deskripsi bahan dan teknik pengumpulan sampel}

Penelitian ini merupakan penelitian cross sectional dengan pengambilan data rekam medis (RM) secara retrospektif awal bulan Maret 2019 di Rumah Sakit Pemerintah di Yogyakarta. Teknik pengambilan data total sampel data rekam medis bulan Januari-Februari 2019. Kriteria inklusi meliputi rekam medis pasien dengan diagnosa bedah ortopedi yang mendapatkan antibiotik profilaksis sejumlah 59 pasien, berusia 13-59 tahun baik laki laki maupun perempuan, tidak memiliki penyakit penyerta yang membahayakan dan infeksi lain. Kriteria eksklusi berupa catatan rekam medik pasien yang tidak terbaca secara jelas dan tidak lengkap. 
213 | Murdiana, H.E./Jurnal Ilmiah Farmasi (Scientific Journal of Pharmacy) 17(2) Agustus-Desember 2021, 210-225

\subsection{Penjelasan mengenai deskripsi jalannya penelitian}

\subsubsection{Observasi angka kejadian bedah ortopedi di Rumah Sakit Pemerintah di Yogyakarta}

Observasi angka kejadian kasus bedah ortopedi di Rumah Sakit Pemerintah di Yogyakarta bertujuan untuk meyakinkan peneliti bahwa bahan penelitian yang berupa rekam medis sesuai dengan inklusi dan eksklusi serta memenuhi kecukupan sampel untuk penelitian.

\subsubsection{Mendaftarkan penelitian untuk mendapatkan persetujuan Etik}

Pengajuan persetujuan etik dilakukan secara online di Komite Etik Penelitian Universitas Ahmad Dahlan (KEP UAD) dengan mengunggah proposal dan mengisi beberapa formulir yang disediakan. Peneliti berdiskusi tentang jalannya penelitian dengan KEP UAD sehingga menghasilkan kesepakatan dan dikeluarkannya Surat Persetujuan Etik No. 021903001 tertanggal 8 Maret 2019.

\subsubsection{Mengumpulkan data rekam medis}

Pengumpulan data rekam medis bulan Januari sampai Februari 2019 dengan diagnosa bedah ortopedi yang mendapatkan terapi antibiotik profilaksis dilakukan pada pertengahan bulan Maret 2019 selama 8 hari kerja.

\subsubsection{Tabulasi data}

Data yang terkumpul sesuai kriteria inklusi dan eksklusi ditabulasi berdasarkan nama, nomor RM, umur, berat badan, pekerjaan, tanggal masuk RS, tanggal keluar RM, diagnosa awal, diagnosa akhir, tes penunjang, alergi, infeksi lain, riwayat penyakit, antibiotik profilaksis pre dan post operasi (nama, dosis, rute dan aturan pakai), obat lain saat di RS, obat dibawa pulang, tanda vital pre dan post operasi, data pembedahan (tanggal, lama, jenis, klasifikasi), tanda klinis, dan pemeriksaan laboratorium. Data yang diperoleh, dikelompokkan sesuai kebutuhan penelitian berdasarkan antibiotik dan obat lain yang diberikan saat rawat inap di RS baik tunggal maupun kombinasi secara rinci termasuk dosis, rute, cara pemberian. Proses bedah ortopedi dikelompokkan untuk mendukung data pemberian obat.

\subsubsection{Analisa data}

Analisa data DRPs meliputi tepat indikasi obat, tepat obat yang diberikan, tepat waktu pemberian, tepat rute pemberian, tepat dosis dengan metode deskriptif analitik dimana hasil berupa persentase kejadian ketepatan obat dari tiap DRPs tersebut.

$$
\text { Ketepatan }=\frac{\text { Jumlah kasus tepat }(1)}{\text { Total kasus (59 subjek penelitian) }} \times 100 \%
$$

Keterangan:

(1) tepat indikasi, tepat obat, tepat waktu pemberian obat, tepat rute dan tepat dosis obat 
Analisis data potensial interaksi obat dengan metode desktiptif analitik berdasarkan literatur terkait dan panduan pada Drug Information Handbook (DIH), AHFS Clinical Dug Informaton serta Stockley's Drug Interaction untuk mengetahui pola penggunaan dan potensial permasalahan pemberian obat yang terjadi. Analisa angka kejadian potensi interaksi disajikan dalam bentuk persentase dengan rumus:

$$
\text { Potensi Interaksi }=\frac{\text { Jumlah kasus interaksi yang terjadi }}{\text { Total kasus (59 subjek penelitian) }} \quad \times 100 \%
$$

\section{Hasil dan pembahasan}

Penelitian dilakukan berdasarkan data rekam medis bulan Januari-Februari 2019 pasien bedah ortopedi di Rumah Sakit Pemerintah Yogyakarta dengan subjek penelitian 59 pasien berdasarkan kriteria inklusi dan eksklusi. Karakteristik pasien dikategorikan menurut usia, jenis kelamin, lama tinggal di Rumah Sakit, jenis tindakan, lama tindakan dan lama tinggal di Rumah sakit. Diagram distribusi data usia pasien terlihat pada Gambar 1.

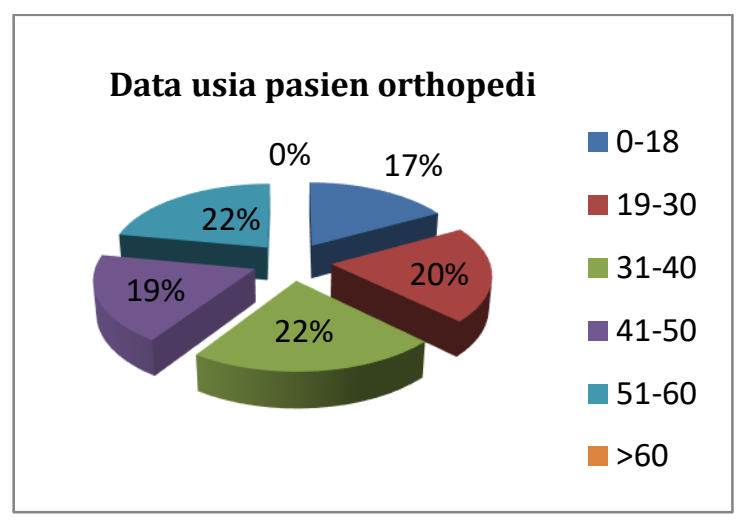

Gambar 1. Distribusi Data Usia Pasien

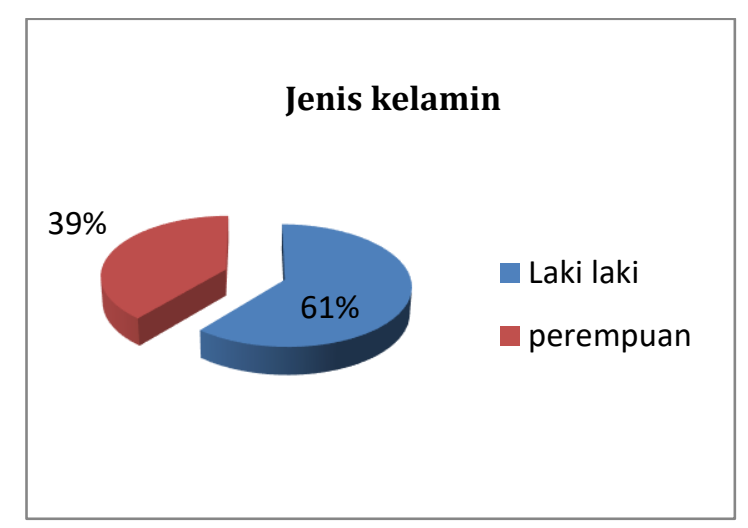

Gambar 2. Distribusi jenis kelamin

Data penelitian menunjukkan bahwa rentang usia 31-40 tahun dan usia 51-60 tahun adalah usia terbanyak kejadian bedah ortopedi yaitu 22\%. Berbeda dengan penelitian Heryanto dkk yang menyatakan fraktur lebih sering terjadi pada laki-laki usia di bawah 45 tahun karena kesalahan olahraga, pekerjaan, atau luka akibat kecelakaan kendaraan bermotor, sedangkan wanita usia lanjut mengalami fraktur disebabkan karena meningkatnya insiden osteoporosis yang terkait dengan perubahan hormon pada menopause (Heryanto et al., 2013). Faktor risiko utama jatuh adalah usia. Tingkat risiko jatuh dapat dipengaruhi oleh perubahan fisik, sensorik, dan kognitif yang 
terkait dengan penuaan (WHO, 2021 ). Data penelitian tentang distribusi jenis kelamin terlihat pada Gambar 2. Terlihat laki laki lebih banyak mengalami tindakan bedah ortopedi dibanding perempuan.

Penelitian ini mendapatkan hasil bahwa 96\% tindakan bedah ortopedi dilakukan secara bersih. Operasi dikatakan bersih jika tidak ditemui peradangan dan tidak ada perlakuan pada saluran pernapasan, saluran pencernaan atau genitourinari serta juga tidak ada jeda dalam teknik ruang operasi aseptik (Healthcare-Improvement-Scotland, 2014; Crader \& Varacallo, 2021). Operasi elektif bersih, bersih terkontaminasi, dan terkontaminasi disarankan menggunakan antibiotik profilaksis untuk mengurangi kejadian ILO. Distribusi jenis tindakan operasi terlihat pada Gambar 3. Lama tindakan pembedahan secara positif terkait dengan risiko infeksi luka dan risiko ini merupakan tambahan dari klasifikasi pembedahan (Healthcare-Improvement-Scotland, 2014). Lama tindakan operasi dalam penelitian ini paling banyak (70\%) antara 45-90 menit. Distribusi lama tindakan pembedahan terlihat pada Gambar 4.

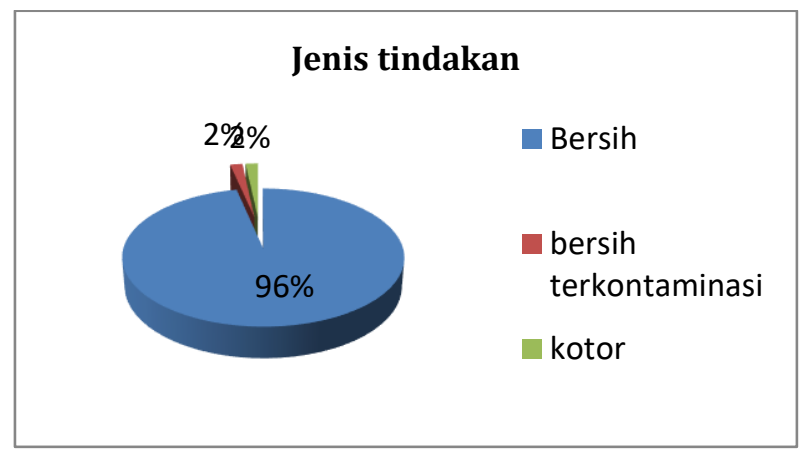

Gambar 3. Distribusi Jenis tindakan bedah

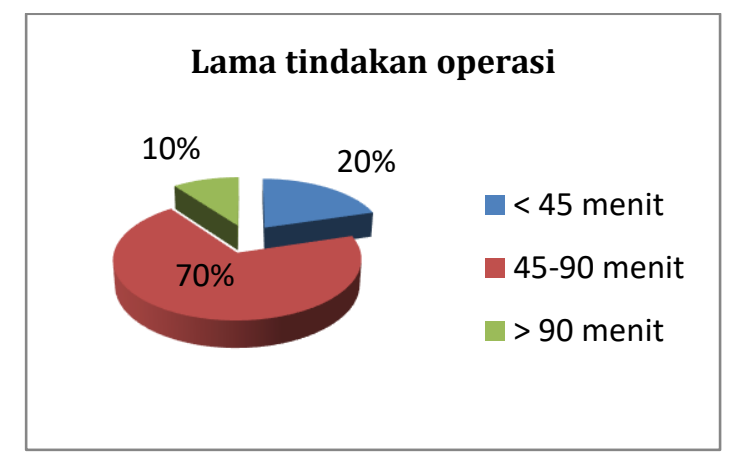

Gambar 4. Distribusi Lama tindakan operasi

Salah satu faktor risiko terjadinya ILO adalah lama tinggal di Rumah Sakit. Dalam penelitian ini ada 34\% pasien bedah ortopedi yang di rawat inap lebih dari 3 hari. Pemberian antibiotik profilaksis untuk bedah berpotensi mempersingkat masa inap di rumah sakit, walaupun bukti untuk manfaat tersebut masih terbatas (Jaeger et al., 2006). Secara jelas distribusi lama tinggal pasien paska bedah ortopedi di rumah sakit terlihat pada Gambar 5. 


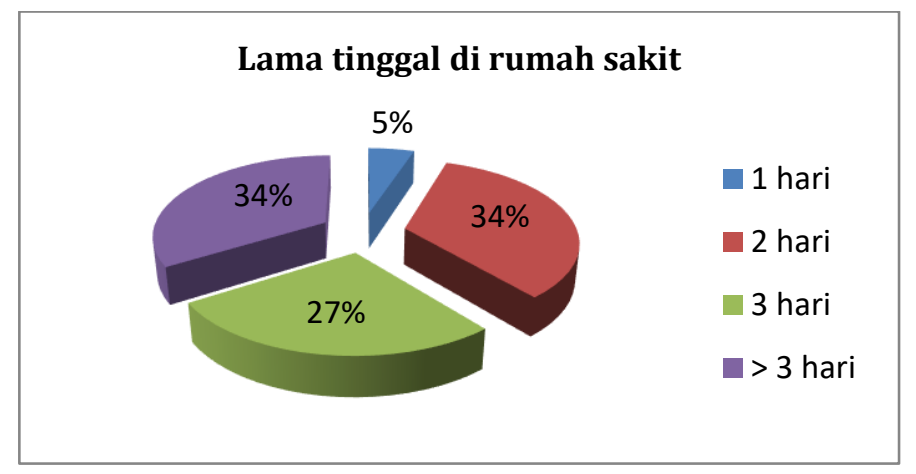

Gambar 5. Distribusi lama tinggal di RS paska bedah ortopedi

Penggunaan antibiotik profilaksis dalam bedah ortopedi efektif dalam mengurangi infeksi lokasi bedah pada artroplasti pinggul dan lutut, bedah tulang belakang, dan reduksi terbuka serta fiksasi internal fraktur. Untuk memaksimalkan efek menguntungkan dari antibiotik profilaksis dan meminimalkan efek samping, agen antimikroba yang tepat harus dipilih, obat harus diberikan sebelum insisi, dan durasi pemberian tidak boleh melebihi 24 jam (Prokuski, 2008). Penggunaan antibiotik profilaksis dalam penelitian ini tergolong profilaksis primer yang mengacu pada pencegahan infeksi awal, sedang profilaksis sekunder mengacu pada pencegahan kekambuhan kembali infeksi yang sudah ada sebelumnya (Bratzler et al., 2013a). Risiko pemberian antibiotik profilaksis bedah terutama terkait dengan konsekuensi dari penggunaan antibiotik yang tidak rasional, yaitu peningkatan prevalensi resistensi antibiotik dan efek samping seperti diare terkait antibiotik dengan atau tanpa superinfeksi menyebabkan kerugian bagi pasien (Jaeger et al., 2006). Pengobatan rasional adalah pengobatan pada pasien dengan terapi obat yang sesuai kebutuhan dalam periode waktu yang tepat dan dengan harga yang paling murah (Kemenkes-RI, 2011). Data yang diamati dalam penelitian ini adalah DRPs berupa ketepatan indikasi, ketepatan obat, ketepatan rute, ketepatan waktu pemberian, ketepatan dosis dan potensi interaksi obat.

\subsection{Antibiotik profilaksis}

\subsubsection{Tepat indikasi}

Tepat indikasi adalah ketepatan pemilihan obat oleh tenaga medis berdasarkan diagnosa pertama kali yang ditegakkan mengacu pada keluhan dan hasil laboratorium. Semua pemberian antibiotik diindikasikan untuk mencegah infeksi awal bedah ortopedik. Indikasi penggunaan antibiotik untuk profilaksis bedah lebih disarankan pada operasi bersih dan bersih terkontaminasi. Sensitivitas dan pola bakteri patogen terbanyak pada kasus tertentu merupakan dasar pemilihan antibiotik profilaksis yang digunakan (Zunnita et al., 2018). Konsentrasi dalam plasma antibiotik profilaksis pada bedah ortopedi disarankan diatas kadar hambat minimum, sehingga pemberian 
harus dilakukan sebelum insisi dan sebelum terjadi infeksi. Dua jam pertama setelah insisi atau sebelum keberadaan kontaminan adalah periode terpenting konsentrasi antibiotik dalam darah yang harus dikelola, sehingga pemberian antibiotik profilaksis di sarankan 1 jam sebelum insisi (Bryson et al., 2016). Antibiotik profilaksis pre pembedahan diberikan hanya pada 14 (23,72\%) pasien dan 76,27\% pasien tidak menerima antibiotik. Semua pasien (100\%) menerima antibiotik pasca pembedahan. Panduan terapi American Society of Health System Pharmacists (ASHP) yang menyatakan bedah ortopedi dengan tindakan operasi bersih melibatkan tangan, lutut atau kaki dan tidak melibatkan implantasi atau material asing tidak disarankan penggunaan antibiotik profilaksis (Bratzler et al., 2013b).

Ketepatan indikasi untuk obat lain yang diberikan setelah antibiotik profilaksis seperti pemberian ketorolac sebagai analgetik bedah dan ranitidin untuk mencegah iritasi akibat penggunaan ketorolac sudah tepat tepat. Ketorolac dosis tunggal yang diberikan secara sistemik efektif mengurangi nyeri paska pembedahan (Bryson et al., 2016).

\subsubsection{Tepat jenis obat}

Sefalosporin generasi I dan II adalah antibiotik yang disarankan untuk profilaksis, sedangkan penggunaan sefalosporin generasi III dan IV tidak dianjurkan (Zunnita et al., 2018 ). Pemilihan antibiotik profilaksis lebih disarankan pada antibiotik yang mempunyai spektrum sempit karena dapat mengurangi risiko resistensi bakteri, pemilihan antibiotik dengan toksisitas rendah, tidak menimbulkan reaksi merugikan atau interaksi dengan obat anestesi, bersifat bakterisidal dan harga terjangkau (Zunnita et al., 2018 ). Pemilihan obat yang tepat dan mempunyai efek terapi terbaik sesuai dengan spektrum penyakit pasien dapat dilakukan setelah diagnosis ditegakkan dengan benar (Kemenkes-RI, 2011). Pada penelitian ini, semua pasien mendapatkan cefotaxim (sefalosporin generasi III) untuk profilaksis bedah. Berbeda dengan penelitian lain, Sefalosporin generasi 2 dan 3 (cefuroxime dan ceftriaxon) banyak digunakan pada profilaksis antibiotik (Narsaria \& Singh, 2017). Pemberian antibiotik profilaksis pada penelitian ini dapat dilihat pada Tabel 1.

Tabel 1. Penggunaan antibiotik profilaksis bedah ortopedi

\begin{tabular}{lcccc}
\hline \multirow{2}{*}{ Obat } & \multicolumn{2}{c}{$\begin{array}{c}\text { Pre pembedahan } \\
\text { n=59 }\end{array}$} & \multicolumn{2}{c}{$\begin{array}{c}\text { Paska Pembedahan } \\
\text { n=599 }\end{array}$} \\
\cline { 2 - 5 } & Frekuensi & Persentase (\%) & Frekuensi & Persentase (\%) \\
\hline Cefotaksim 2 x 1g inj. & 14 & 23,72 & 59 & 100 \\
Tanpa antibiotik & 45 & 76,27 & 0 & 0 \\
\hline
\end{tabular}

Pada operasi tulang belakang dengan atau tanpa instrumen, operasi patah tulang pinggang, implantasi perangkat internal (seperti kuku), pergantian sendi antibiotik yang direkomendasikan 
adalah cefazolin (Bratzler et al., 2013b). Pemberian cefotaxim pada bedah meskipun bukan obat pilihan untuk profilaksis, tetap harus diberikan sebelum pembedahan untuk meyakinkan kekuatan cefotaxim pada jaringan dan saat pembedahan (AHFS, 2011). Pada penelitian ini ada 76,27\% tidak diberikan profilaksis preoperasi. Penelitian tentang penetrasi cefotaxim secara difusi pasif ke tulang masih jarang. Hamdan dkk (2019) melakukan penelitian pada 26 pasien yang diberi 1g cefotaxim IV, Cefotaxim diekstrak dari nukleus pulposus dan serum kemudian dianalisis kadarnya dengan HPLC memberi hasil bahwa konsentrasi cefotaxim pada 16 sampel dibawah hambat minimum konsentrasi melawan staphylococcus aureus, dan terjadi pelonjakan konsentrasi pada jam ke-3 setelah pemberian sehingga cefotaxim perlu diberikan 2 jam sebelum tindakan dan pemberian dosis berulang segera sebelum operasi untuk menjaga konsentrasi serum tetap tinggi (Hamdan et al., 2019). Organisme yang paling umum menyebabkan infeksi adalah Staphylococcus aureus, Staphylococcus negatif koagulase dan basil gram negatif (Narsaria \& Singh, 2017). Cefotaxim aktif melawan banyak organisme gram negatif dan anaerob yang lebih sering menyebabkan infeksi nosokomial. cefotaksim dosis tunggal, $1 \mathrm{~g}$ atau $2 \mathrm{~g}$ yang diberikan 30 menit sebelum operasi, telah terbukti efektif sebagai profilaksis untuk infeksi setelah prosedur pembedahan. Cefotaxim dosis tunggal lebih efektif daripada dosis ganda ( $p<0,01$ ) (Gentry, 1990). Dengan demikian, pada penelitian ini, penggunaan cefotaxim sebagai profilaksis bedah sudah tepat dengan persentase 100\% meskipun bukan sebagai pilihan pertama. Begitu juga obat yang diberikan bersamaan dengan profilaksis sudah tepat yaitu ranitidin berfungsi untuk meminimalisir efek samping pemberian ketorolac dibanding H2-blocker lain. Pemberian ketorolac sebagai analgetik mempertimbangkan harga yang terjangkau, walaupun potensi efek samping perdarahan GI sangat potensial jika tanpa ranitidin.

\subsubsection{Tepat waktu pemberian}

Cefotaxim digunakan untuk profilaksis perioperatif pada bedah terkontaminasi atau potensial terkontaminasi harus dipastikan bahwa pasien menerimanya secara intravena atau intramuscular 30 hingga 90 menit sebelum tindakan bedah (AHFS, 2011). Pendapat lain, pemberian awal profilaksis antibiotik disarankan 60 menit sebelum pembedahan (Backes et al., 2017). Pada penelitian ini, hanya $23,73 \%$ pasien yang menerima cefotaxim pre pembedahan, namun waktu pemberian secara detail tidak terdokumentasi dalam rekam medis. Pedoman Pengendalian Infeksi Pusat Pengendalian Penyakit CDC merekomendasikan bahwa antibiotik harus diberikan kembali jika durasi operasi diperkirakan melebihi waktu (Narsaria \& Singh, 2017). Waktu paruh cefotaxim 
pada pasien dewasa dengan fungsi ginjal baik adalah 0,9-1,7 jam. Pemberian dosis berulang direkomendasikan 3 jam setelah pemberian cefotaxim awal (Bratzler et al., 2013b).

\subsubsection{Tepat rute pemberian obat}

Rute pemberian profilaksis cefotaxim 100\% tepat secara intravena. Rute pemberian obat lain sudah tepat sesuai dengan kebutuhan pasien. Data rute pemberian obat lain terlihat pada Tabel 3.

\subsubsection{Tepat dosis}

Dosis lazim cefotaxim sebagai antibiotik profilaksis pada kasus bedah secara umum adalah 1g untuk dewasa tetapi pada kasus pasien obesitas bisa ditingkatkan hingga 2 g. Dosis pada Pediatri $50 \mathrm{mg} / \mathrm{kg}$ tetapi tidak boleh melebihi dosis dewasa (Bratzler et al., 2013b). Pemberian dosis cefotaxim profilaksis pre pembedahan dalam penelitian ini $1 \mathrm{~g}$ x 2 pada 14 pasien $(23,73 \%)$ tanpa memperhatikan status obesitas pasien. Menurut literatur pemberian cefotaksim profilaksis pre pembedahan direkomendasikan dosis $1 \mathrm{~g}$ dan pemberian dosis berulang 3x setelah dosis pertama pre pembedahan (Bratzler et al., 2013b). Ada 14 pasien (23,73\%) mendapatkan 2g sebelum pembedahan sehingga dosis tepat. Beberapa penelitian menyatakan pemberian antibiotik profilaksis pada berat badan lebih dari $60 \mathrm{~kg}$ maksimal 2 gram, tetapi hanya berdasarkan para ahli dan data farmakokinetik, sedangkan bukti yang berkualitas baik tidak ada (Backes et al., 2017). Bukti dalam literatur medis tidak dapat menunjukkan manfaat tambahan antibiotik paska pembedahan lebih baik dibanding profilaksis pra pembedahan. Pemberian dosis yang berlebih tidak membawa manfaat pada durasi efikasi antibiotik, biaya perawatan kesehatan, dan efek eradikasi flora mikroba pasien (Lundine et al., 2010). Dari data tersebut dapat disimpulkan ada $23,73 \%$ pasien yang menerima profilaksis per pembedahan dan $100 \%$ mendapatkan dosis tepat untuk paska pembedahan.

Paska pemberian antibiotik profilaksis pasien mendapatkan terapi farmakologi untuk mengelola gejala yang timbul seperti nyeri paska bedah, efek samping pemberian anestesi bedah dan gejala lain yang menyertainya. Ketepatan penggunaan obat selain antibiotik profilaksis dapat dilihat pada Tabel 2 . 
220 | Murdiana, H.E./Jurnal Ilmiah Farmasi (Scientific Journal of Pharmacy) 17(2) Agustus-Desember 2021, 210-225

Tabel 2. Penggunaan obat selain antibiotik profilaksis

\begin{tabular}{|c|c|c|c|c|}
\hline Nama Obat & Indikasi & $\begin{array}{c}\text { Rute } \\
\text { pemberian }\end{array}$ & $\begin{array}{c}\text { Dosis } \\
\text { pemberian }\end{array}$ & Keterangan \\
\hline Ketorolac & Analgetik & iv & $30 \mathrm{mg}(3 \times 1)$ & $\begin{array}{l}\text { 1. Dosis lazim } 30 \\
120 \mathrm{mg} / \text { hari, rute iv } \\
\text { 2. Dosis pemberian } \\
\text { sesuai } \\
\text { 3. Diberikan pada } \\
\text { seluruh pasien } 59 \\
\text { pasien) }\end{array}$ \\
\hline Ranitidin & $\begin{array}{l}\text { Mencegah iritasi } \\
\text { ketorolac yang } \\
\text { menyebabkan } \\
\text { pendarahan GI }\end{array}$ & iv & $50 \mathrm{mg}(3 \times 1)$ & $\begin{array}{l}\text { 1. Dosis lazim } 150 \mathrm{mg} \\
(2 \times 1) \text { atau } 300 \mathrm{mg} \\
\text { 2. Dosis pemberian } \\
\text { belum sesuai (dosis } \\
\text { kurang) } \\
\text { 3. Diberikan pada } \\
\text { seluruh pasien }(59 \\
\text { pasien) }\end{array}$ \\
\hline Na diklofenak & Analgetik & po & $50 \mathrm{mg}(3 \times 1)$ & Dosis pemberian sesuai \\
\hline Metoklorpamid & $\begin{array}{l}\text { Antiemetik } \\
\text { pasca } \\
\text { pembedahan }\end{array}$ & iv & $10 \mathrm{mg}$ & $\begin{array}{l}\text { 1. Dosis lazim } 10 \mathrm{mg} \\
\text { secara iv/im pasca } \\
\text { pembedahan } \\
\text { 2. Hanya } 1 \text { pasien, } \\
\text { kondisi khusus } \\
\text { 3. Dosis pemberian } \\
\text { sesuai }\end{array}$ \\
\hline $\begin{array}{l}\text { Metilprednisolon } \\
\text { combivent } \\
\text { (Ipratropium Br } \\
\text { dosis } 0,52 \mathrm{mg} \text {, } \\
\text { Salbutamol } \\
\text { sulphate dosis } \\
3,01 \mathrm{mg} \text { ) } \\
\text { flexotide } \\
\text { Fluticasone } \\
\text { propionate } 0,5 \mathrm{mg} / \\
2 \text { mL) }\end{array}$ & Antiasma & $\begin{array}{c}\text { iv } \\
\text { nebul }\end{array}$ & $\begin{array}{l}125 \mathrm{mg} \\
1 \text { vial }\end{array}$ & $\begin{array}{l}\text { 1. Dosis } \\
\text { metilprednisolon } \\
\text { untuk asma akut } 125 \\
\text { mg } \\
\text { 2. Dosis untuk nebul } \\
\text { menyesuaikan } \\
\text { kondisi pasien } \\
\text { 3. Hanya } 1 \text { pasien, } \\
\text { kondisi khusus }\end{array}$ \\
\hline Sitokolin & Neuroprotection & po & $500 \mathrm{mg}$ & $\begin{array}{l}\text { 1. Dosis lazim sitokolin } \\
500-2000 \mathrm{mg} / \mathrm{hari} \\
\text { 2. Dosis pemberian } \\
\text { sesuai }\end{array}$ \\
\hline Mekobalamin & Neuroprotection & po & $500 \mathrm{mcg}(2 \times 1)$ & $\begin{array}{l}\text { Dosis mekobalamin } \\
500 \mathrm{mcg}\end{array}$ \\
\hline Piracetam & Nootropik & iv & $2 \mathrm{~g}(3 \times 1)$ & $\begin{array}{l}\text { 1. Dosis lazim 1g 3x } \\
\text { sehari } \\
\text { 2. Dosis pemberian } \\
\text { belum sesuai (dosis } \\
\text { berlebih) } \\
\text { 3. Hanya 1 pasien }\end{array}$ \\
\hline
\end{tabular}


221 | Murdiana, H.E./Jurnal Ilmiah Farmasi (Scientific Journal of Pharmacy) 17(2) Agustus-Desember 2021, 210-225

Pemberian ranitidin sebagai profilaksis iritasi ketorolac diberikan dibawah dosis lazim. Dosis lazim ranitidin 300mg/ hari dalam dosis tunggal maupun terbagi 2, berarti $100 \%$ pasien mengalami dosis kurang untuk ranitidin. Dosis metilprednisolon untuk asma akut 125mg, sesuai dengan penelitian Emerman dan Cydulka (1995) menyatakan bahwa pemberian metilprednisolon dosis 125mg dibandingkan 40mg dan $20 \mathrm{mg}$ jauh memberikan perbaikan yang cepat di hari pertama.

\subsubsection{Potensi interaksi obat}

Potensi interaksi obat lain yang diberikan bersama antibiotik profilaksis saat rawat inap berdasarkan buku Drug Interaction Fact (Tatro, 2012), Stockly's Drug Interaction (Stockly, 2008), Drug Interaction Handbook (Lacy et al., 2009 ), AHFS Drug Information (Lacy et al., 2009 ) terlihat pada Tabel 3.

Tabel 3. Potensial interaksi obat pada pasien bedah ortopedi

\begin{tabular}{|c|c|c|c|c|c|c|}
\hline $\begin{array}{c}\text { Interaksi } \\
\text { Obat }\end{array}$ & $\begin{array}{c}\text { Drug } \\
\text { Interaction } \\
\text { Facts }\end{array}$ & Stockly & DIH & AHFS & $\begin{array}{l}\text { Jumlah } \\
\text { (N) }\end{array}$ & $\begin{array}{l}\text { Persen- } \\
\text { tase (\%) }\end{array}$ \\
\hline $\begin{array}{l}\text { Ketorolac- } \\
\text { Ranitdin }\end{array}$ & $\begin{array}{l}\text { Signifikansi =5 } \\
\text { Onset= tertunda } \\
\text { Keparahan= } \\
\text { minor } \\
\text { Efek terapetik } \\
\text { NSAIDs mungkin } \\
\text { berubah }\end{array}$ & $\begin{array}{l}\text { H2 Blocker } \\
\text { melindungi } \\
\text { mukosa GI } \\
\text { dari efek } \\
\text { iritasi NSAIDs }\end{array}$ & & & 59 & 100 \\
\hline $\begin{array}{l}\text { Ketorolac } \\
\text { (NSAID) + } \\
\mathrm{Na} \\
\text { diklofenak } \\
\text { (NSAID) }\end{array}$ & & $\begin{array}{l}\text { Meningkatkan } \\
\text { ESO berupa } \\
\text { pendarahan GI } \\
\text { parah }\end{array}$ & & $\begin{array}{l}\text { Meningkatka } \\
\text { n ESO } \\
\text { pendarahan } \\
\text { GI }\end{array}$ & 3 & 5,08 \\
\hline $\begin{array}{l}\text { Diklofenak } \\
\text { (NSAID) + } \\
\text { Ranitidin }\end{array}$ & & $\begin{array}{l}\text { Farmakokineti } \\
\text { k diklofenak } \\
\text { tidak } \\
\text { terpengaruh } \\
\text { dengan } \\
\text { ranitidin dan } \\
\text { sebaliknya }\end{array}$ & & & 3 & 5,08 \\
\hline $\begin{array}{l}\text { NSAID } \\
\text { (ketorolac) } \\
+ \text { ACEI } \\
\text { (kaptopril) }\end{array}$ & & $\begin{array}{l}\text { Kombinasi } \\
\text { NSAID dan } \\
\text { ACEI mungkin } \\
\text { meningkatkan } \\
\text { resiko } \\
\text { kerusakan } \\
\text { renal, jarang } \\
\text { menimbulkan } \\
\text { hiperkalemia }\end{array}$ & $\begin{array}{l}\text { Kombinasi } \\
\text { dari NSAID } \\
\text { dan ACE } \\
\text { inhibitor } \\
\text { dapat } \\
\text { meningkat } \\
\text { kan risiko } \\
\text { gangguan } \\
\text { ginjal dan } \\
\text { hiperkalem }\end{array}$ & $\begin{array}{l}\text { Meningkatka } \\
\text { n resiko } \\
\text { kerusakan } \\
\text { ginjal pada } \\
\text { pasien } \\
\text { hipovolemia }\end{array}$ & 1 & 1,69 \\
\hline
\end{tabular}


222 | Murdiana, H.E./Jurnal Ilmiah Farmasi (Scientific Journal of Pharmacy) 17(2) Agustus-Desember 2021, 210-225

\begin{tabular}{|c|c|c|c|c|c|c|}
\hline $\begin{array}{c}\text { Interaksi } \\
\text { Obat }\end{array}$ & $\begin{array}{c}\text { Drug } \\
\text { Interaction } \\
\text { Facts }\end{array}$ & Stockly & DIH & AHFS & $\begin{array}{l}\text { Jumlah } \\
\text { (N) }\end{array}$ & $\begin{array}{l}\text { Persen- } \\
\text { tase (\%) }\end{array}$ \\
\hline & & & ia & & & \\
\hline $\begin{array}{l}\text { NSAID } \\
\text { (ketorolac) } \\
+ \text { bisoprolol }\end{array}$ & & & $\begin{array}{l}\text { ketorolac } \\
\text { menurunka } \\
\text { n efek } \\
\text { antihiperte } \\
\text { nsi } \\
\text { bisoprolol }\end{array}$ & & 1 & 1,69 \\
\hline $\begin{array}{l}\text { Bisoprolol } \\
\text { (B-blocker) } \\
+ \text { Kalsium }\end{array}$ & & & $\begin{array}{l}\text { Absorbsi B- } \\
\text { bloker } \\
\text { menurun } \\
\text { dengan } \\
\text { adanya } \\
\text { kalsium }\end{array}$ & & 1 & 1,69 \\
\hline $\begin{array}{l}\text { Kalsium } \\
\text { +Vitamin C }\end{array}$ & & & & & 1 & 1,69 \\
\hline $\begin{array}{l}\text { Paracetamol } \\
+ \text { Ranitidin }\end{array}$ & & & & $\begin{array}{l}\text { Ranitidin } \\
\text { menghambat } \\
\text { metabolism } \\
\text { paracetamol }\end{array}$ & 2 & 3,39 \\
\hline
\end{tabular}

Penggunaan ketorolac sebagai pereda nyeri direkomendasikan tidak lebih dari 5 hari dengan dosis 30-120mg/hari. Efek samping penggunaan ketorolac adalah perdarahan gastrointestinal (GI), sehingga harus dimonitor penggunaannya. Mekanisme kerja ketorolac menghambat sintesis prostaglandin dengan menurunkan aktifitas enzim cyclooxygenase yang menyebabkan penurunan prekursor prostaglandin (Vacha et al., 2015). Golongan H2-blocker melindungi mukosa GI terhadap efek iritasi yang disebabkan NSAID, sehingga penggunaan bersama sangat menguntungkan (Lacy et al., 2009). Ada 5 kasus (8,4\%) pemberian NSAID lebih dari 1 macam, interaksi ini sangat merugikan karena dapat meningkatkan efek samping berupa perdarahan GI. Resiko penggunaan NSAID oral dapat direduksi dengan hanya menggunakan 1 jenis NSAID saja (Stockly, 2008). Ditemukan 1 kasus (1,69\%) penggunaan vitamin C dengan kalsium. Penggunaan vitamin $\mathrm{C}$ dikombinasi dengan kalsium, akan meningkatkan absorbsi kalsium pada usus (Morcos et al., 1976). Keterbatasan penelitian ini adalah peneliti tidak dapat mengamati langsung kejadian interaksi pada pasien karena penelitian dilaksanakan secara retrospektif, sehingga perlu dilakukan penelitian secara prospektif untuk menganalisa penggunaan antibiotik profilaksis. 


\section{Kesimpulan}

Data DRPs menunjukkan semua pasien mendapat terapi rasional berupa tepat indikasi, tepat jenis obat, tepat rute pemberian dan dosis pemberian untuk profilaksis antibiotik pre maupun paska pembedahan. Waktu pemberian antibiotik profilaksis secara detail tidak ada data. Pemberian obat selain antibiotik profilaksis pada semua terapi ranitidin menunjukkan dosis kurang dan 1,69\% terapi piracetam dosis berlebih. Potensial interaksi yang terjadi meliputi ketorolak-ranitidin, NSAID dengan NSADI lain, NSAID - ranitidin, NSADI- ACEI, NSAID-bisoprolol, bisoprolol-kalsium, kalsiumvitamin C dan paracetamol-ranitidin.

\section{Ucapan terimakasih}

Penulis mengucapkan terimakasih kepada Kemenristekdikti atas dana hibah penelitian tahun 2019 dalam skema penelitian dosen pemula serta semua teman yang membantu dan mendukung penelitian ini.

\section{Daftar pustaka}

AHFS. (2011). AHFS Drug Information. (gerald K. McEvory ed.): American Society of Health System Pharmacist.

Asrawal, A., Summary, R., Hasan, D., \& Daniel, D. (2019). Faktor risiko terjadinya infeksi daerah operasi pada pasien bedah orthopedi di RSUP Fatmawati periode Juli-Oktober 2018. Jurnal Sains Farmasi \& Klinis, 6, 104. doi:10.25077/jsfk.6.2.104-112.2019

Backes, M., Dingemans, S. A., Dijkgraaf, M. G. W., van den Berg, H. R., van Dijkman, B., Hoogendoorn, J. M., Joosse, P., Ritchie, E. D., Roerdink, W. H., Schots, J. P. M., Sosef, N. L., Spijkerman, I. J. B., Twigt, B. A., van der Veen, A. H., van Veen, R. N., Vermeulen, J., Vos, D. I., Winkelhagen, J., Goslings, J. C., \& Schepers, T. (2017). Effect of antibiotic prophylaxis on surgical site infections following removal of orthopedic implants used for treatment of foot, ankle, and lower leg fractures: A randomized clinical trial. Jama, 318(24), 2438-2445. doi:10.1001/jama.2017.19343

Bratzler, D. W., Dellinger, E. P., Olsen, K. M., Perl, T. M., Auwaerter, P. G., Bolon, M. K., Fish, D. N., Napolitano, L. M., Sawyer, R. G., Slain, D., Steinberg, J. P., \& Weinstein, R. A. (2013a). Clinical practice guidelines for antimicrobial prophylaxis in surgery. Surg Infect (Larchmt), 14(1), 73-156. doi:10.1089/sur.2013.9999

Bratzler, D. W., Dellinger, E. P., Olsen, K. M., Perl, T. M., Auwaerter, P. G., Bolon, M. K., Fish, D. N., Napolitano, L. M., Sawyer, R. G., Slain, D., Steinberg, J. P., \& Weinstein, R. A. (2013b ). Clinical practice guidelines for antimicrobial prophylaxis in surgery. In ASHP Therapeutic Guidelines, 14 (1), 73-156. doi:https://doi.org/10.1089/sur.2013.9999 
Bryson, D. J., Morris, D. L., Shivji, F. S., Rollins, K. R., Snape, S., \& Ollivere, B. J. (2016). Antibiotic prophylaxis in orthopaedic surgery: difficult decisions in an era of evolving antibiotic resistance. Bone Joint J, 98-b(8), 1014-1019. doi:10.1302/0301-620x.98b8.37359

Crader, M. F., \& Varacallo, M. (2021). Preoperative antibiotic prophylaxis. In StatPearls. Treasure Island (FL): StatPearls Publishing LLC.

Davat, M., Wuarin, L., Stafylakis, D., Abbas, M., Harbarth, S., Hannouche, D., \& Uçkay, I. (2018). Should antibiotic prophylaxis before orthopedic implant surgery depend on the duration of pre-surgical hospital stay? Antimicrob Resist Infect Control, 7, 131. doi:10.1186/s13756018-0421-2

Dhammi, I. K., Ul Haq, R., \& Kumar, S. (2015). Prophylactic antibiotics in orthopedic surgery: Controversial issues in its use. Indian J Orthop, 49(4), 373-376. doi:10.4103/00195413.159556

Dinata, P. A. W. (2018). Evaluation rasionalitas penggunaan antibiotik profilaksis pada pasien bedah tulang fraktur terbuka ekstrimitas bawah di Rumah Sakit Orthopedi Prof.Dr Soeharso Surakarta tahun 2017 (Bachelor). Universitas Muhammadiyah Surakarta, Retrieved from http://eprints.ums.ac.id/id/eprint/65405

Emerman, C. L., \& Cydulka, R. K. (1995). A randomized comparison of 100-mg vs 500-mg dose of methylprednisolone in the treatment of acute asthma. Chest 107(6), 1559-1563. doi:https://doi.org/10.1378/chest.107.6.1559

Gentry, L. O. (1990). Cefotaxime and prophylaxis. New approaches with a proven agent The American Journal of Medicine, 88(4), S32-S37. doi:https://doi.org/10.1016/00029343(90)90325-8

Hamdan, T. A., hashim, M. S., Haddad, N. S., \& Jawad, A. M. (2019). Penetration of cefotaxime into intervertebral discs removed from patients undergoing discectomy. Basrah Journal of Surgery, 25(1), 3-9. doi:10.33762/bsurg.2031.162890

Healthcare-Improvement-Scotland. (2014). SIGN 104. Antibiotic prophylaxis in surgery (Issue July 2008). Retrieved from http://www.sign.ac.uk

Heryanto, R., Rakhmat, A., \& Ismail, I. (2013). Faktor-faktor yang berhubungan dengan terjadinya infeksi pada pasien fraktur terbuka di Ruang Bedah Lontar 2 Orthopedoi RSUP Dr Wahidin Sudirohusodo Makasar. Scientific Journal of Health Diagnosis, 2(4), 1-9.

Jaeger, M., Maier, D., Kern, W. V., \& Südkamp, N. P. (2006). Antibiotics in trauma and orthopedic surgery-a primer of evidence-based recommendations. Injury, Int J. Care Injured 37, S74S80. doi: https://doi.org/10.1016/J.INJURY.2006.04.012

Jamal, I., Amin, F., Jamal, A., \& Saeed, A. (2015). Pharmacist's interventions in reducing the incidences of drug related problems in any practice setting. International Current Pharmaceutical Journal, 4. doi:10.3329/icpj.v4i2.21483

Kemenkes-RI. (2011). Modul penggunaan obat rasional. Jakarta: Kementrian Kesehatan Republik Indonesia.

Kemenkes-RI. (2013). Riset kesehatan dasar. Jakarta: Badan Penelitian dan Pengembangan Kesehatan Kementrian Kesehatan RI. Retrieved from https://doi.org/1

Lacy, C. F., Amstrong, L. L., \& Goldman, M. P. (2009 ). Drug Information Handbook (17 ed.): LexiComp for the American Pharmacists Association. 
Lundine, K. M., Nelson, S., Buckley, R., Putnis, S., \& Duffy, P. J. (2010). Adherence to perioperative antibiotic prophylaxis among orthopedic trauma patients. Can J Surg, 53(6), 367-372.

Marsaoly, S. F. A. (2016). Infeksi luka post operasi pada pasien post operasi di Bangsal Bedah RS PKU Muhammadiyah Bantul. (Bachelor). Universitas Muhammadiyah Yogyakarta, Yogyakarta.

Mil, J. W. F. v., Horvat, N., \& Westerlund, T. (2019). PCNE Classification for Drug related problems V9.00, 1-10.

Morcos, S. R., El-Shobaki, F. A., El-Hawary, Z., \& Saleh, N. (1976). Effect of vitamin C and carotene on the absorption of calcium from the intestine. Zeitschrift für Ernährungswissenschaft, 15(4), 387-390. doi:10.1007/BF02020506

Narsaria, N., \& Singh, A. (2017). Role of prophylactic antibiotics in orthopaedics: current concepts. EC Orthopaedics, 7(1), 1-2.

Prokuski, L. (2008). Prophylactic antibiotics in orthopaedic surgery. J Am Acad Orthop Surg, 16(5), 283-293. doi:10.5435/00124635-200805000-00007

Radji, M., Aini, F., \& Fauziyah, S. (2014). Evaluation of antibiotic prophylaxis administration at the orthopedic surgery clinic of tertiary hospital in Jakarta, Indonesia: Asian Pac J Trop Dis, 4(3), 190-3. doi: 10.1016/S2222-1808(14)60503-X.

Saffanah, N. I. J. U. ( 2020). Antibiogram kasus infeksi luka operasi pasca bedah orthopedi RSD Dr Soebandi Kabupaten Jember Periode januari-Desember 2019 (Bachelor). Universitas Jember, Jember. Retrieved from http://repository.unej.ac.id/handle/123456789/102067

Stockly, I. H. (2008). Stockley's Drug Interaction. In K. Baxter, S. Sweetman, M. Davies, C. R. Lee, R. McClarney, J. McGlashan, \& P. S. Leger (Eds.) (8 ed. Vol. 8): Pharmaceutical Press.

Tatro, D. S. (2012). Drug Interaction Facts (L. R. Borgsdof, T. A. Golper, R. C. Hagemann, E. A. Hartshorn, \& S. K. Habel (eds.); 6th ed.): Fact and Comparison.

Vacha, M. E., Huang, W., \& Mando-Vandrick, J. (2015). The role of subcutaneous ketorolac for pain management. Hosp Pharm, 50(2), 108-112. doi:10.1310/hpj5002-108

WHO. (2021). Falls. Retrieved from https://www.who.int/news-room/fact-sheets/detail/falls

Yekti, Y. U. (2008). Kajian penggunaan profilaksis dan evaluasi drug related problemnya pada bedah orthopedi kasus fraktur di Unit Bedah RS Panti Rapih Yogyakarta Periode Agustus-September 2007. Universitas Sanata Dharma, Yogyakarta. Retrieved from http://repository.usd.ac.id/id/eprint/16851

Zunnita, O., Sumarny, R., \& Kumalawati, J. ( 2018 ). Pengaruh antibiotik profilaksis terhadap kejadian infeksi luka operasi. Fitofarmaka, 8(1), 39-45. 